\title{
POST-TREATMENT OF PALM OIL MILL EFFLUENT USING ZEOLITE AND WASTEWATER
}

\section{HOSSEIN FARRAJI*; REZA MOHAMMADPOUR ${ }^{\star \star}$ and NASTAEIN QAMARUZ ZAMAN*}

\begin{abstract}
The palm oil mill effluent (POME) is one of the most important ecosystems hazard and can become a crucial environmental burden if discharged without any treatment to nature. The present study aimed to develop a fast method for post-treatment of POME. To enhance treatment process, the domestic wastewater (DWW) and zeolite were added to the sequencing batch reactor (SBR) as the available microbial source and new adsorbent, respectively. The results indicate that the chemical oxygen demand (COD), biochemical oxygen demand (BOD), total suspended solids (TSS), ammonia nitrogen (AN) and colour removal rates were in the range of $95.34 \%-98.31 \%, 88.79 \%-91.44 \%, 95.47 \%-98.95 \%, 96.19 \%-98.30 \%$ and $56.94 \%-81.64 \%$, respectively. Moreover, SBR with both DWW and zeolite addition was able to remove high percentage of all pollution compared to only DWW addition (with a removal percentage of $77 \%$ TSS, $74 \%$ COD, $76 \%$ colour and 90\% AN) or zeolite (23\% TSS, 10\% COD, 9.6\% colour and 80\% AN). The response surface methodology (RSM) was used to elucidate response surface and optimise the independent variables. The highest desirability of POME treatment (0.988) was achieved in optimum operation conditions. Under these conditions, COD, BOD, colour, AN and TSS removal rates were $96.80 \%, 90.1 \%, 69.90 \%, 98.20 \%$ and $97.20 \%$, respectively.
\end{abstract}

\section{Keywords: zeolite, wastewater, palm oil mill effluent, adsorption, sequencing batch reactor.}

Received: 9 February 2019; Accepted: 16 June 2020; Published online: 5 October 2020.

\section{INTRODUCTION}

The industry of palm oil has rapidly developed over the last decades. In Malaysia, the palm oil is considered as a major part of agro-economy with a production of $39 \%$ in the world (Moradi et al., 2015; Wong et al., 2015). However, a great amount of palm oil mill effluent (POME) is generated due

* Faculty of Civil Engineering,

Universiti Sains Malaysia, Seri Ampangan,

14300 Nibong Tebal, Pulau Pinang, Malaysia.

** Department of Civil Engineering,

Estahban Branch, Islamic Azad University,

Estahban, Iran.

E-mail: reza564@gmail.com to high production of palm oil. $\mathrm{Ng}$ et al. (2012) indicated that with production of 94 million tonnes of fresh fruit bunch (FFB), more than 60 million tonnes POME is produced. The POME with high total solids (43 $635 \mathrm{mg}^{\text {litre }}{ }^{-1}$ ), average chemical oxygen demand (COD) and biochemical oxygen demand (BOD) of 70000 and $30000 \mathrm{mg} \mathrm{litre}^{-1}$, respectively can be considered as the main reason for ecosystem and environmental hazard if it is discharged without any treatment (Chan et al., 2012; Ma et al., 1993). Liew et al. (2015) showed that COD, $\mathrm{BOD}$, total suspended solids (TSS), and colour are the most serious contaminants in POME. A range of BOD / COD ratio between 0.29 and 0.62 indicates that the POME is a highly polluted agro-industry 
wastewater that should be treated using biological methods (Mohan and Karthikeyan, 1997; Chan et al., 2010; Vijayaraghavan et al., 2007; Metcalf and Eddy, 2014; Khemkhao et al., 2015).

Generally, several treatment systems have been applied to improve POME quality such as sequencing batch reactor (SBR), up-flow anaerobic sludge bioreactor, added chemical and biochemical productions, enhanced waste stabilisation ponds (aerated lagoon), membrane bioreactor, waste stabilisation pond, extended aeration activated sludge and membrane filters (Aziz et al., 2011a, b). However, the open tank digester and ponding methods are the most popular and commonly used systems to treat POME. Although the ponding systems were suggested as the costeffective techniques for treatment of POME, several disadvantages were observed in these systems such as the big size of the digester, off odour, long treatment duration, insufficient effluent quality, colour, large variation in effluent quality, and large footprint. In order to overcome the problems and improve POME treatment, a high-rate anaerobic bioreactor system has been recommended with smaller foot print and high efficiency such as upflow anaerobic sludge bioreactor (Najafpour et al., 2006), improved anaerobic baffled bioreactor (Setiadi and Husaini, 1996; Faisal and Unno, 2001) and anaerobic fluidised bed bioreactor (Borja and Banks, 1995). Yacob et al. (2006) reported that compared to conventional methods, the anaerobic bioreactors remove more pollution at shorter hydraulic retention time and provide better treatment efficiencies.

Although, the anaerobic pond is one of the most commonly used methods for POME treatment, the effluent of this method can hardly fulfil the standard level of discharge defined by the Malaysian Department of Environment (DOE) (Chan et al., 2010). In order to meet the DOE levels, an appropriate post-treatment is essential for POME discharge. Ho and Tan (1983) reported that the aerobic technologies should be applied as a post-treatment system to reduce pollution of POME within the standards rate. Nasrullah et al. (2017) proposed a post-treatment method for colour removal of POME using electrocoagulation. They reported that this method was effective and slightly expensive for POME treatment. Moreover, phytoremediation was recommended as another laboratory-scale and plant-based post-treatment that is often used for anaerobically treated and diluted POME (Darajeh et al., 2014). For treatment of the industrial and municipal wastewater, the anaerobic-aerobic processes using reactors have been recommended as an effective method with less sludge production, low energy and higher treatment efficiency (Jenícek et al., 1999; Garbossa et al., 2005; Chan et al., 2010; 2011). Although, the conventional anaerobic-aerobic methods have been able to successfully treat the POME, their low organic loading rate (OLR), long hydraulic retention time (HRT), and large space requirement are the disadvantage of these methods. Chou et al. (2016) reported that only a few studies are available in literature related to aerobic post-treatment of anaerobically digested POME and more effort is required to understand the performance of these treatments.

Since the conventional method have no high potential to treat POME, various methods have been proposed to solve this problem such as adsorption, advanced oxidation processes, membrane filtration and coagulation/flocculation. Recently, SBR with a simple configuration of the tank was recommended as a new system with the low-space requirement and effective technique for treatment of industrial and municipal wastewater (Aziz et al., 2012). Ahmad et al. (2003) indicated that flocculation is one of the effective method to remove turbidity in POME. Moussavi et al. (2011) showed that zeolite has high ability in coagulation and flocculation of suspended particle. Recently, SBR with a simple configuration of the tank was recommended as a new system with the low-space requirement and effective technique for treatment of industrial and municipal wastewater (Aziz et al., 2012). Compared to other biological treatment methods, the SBR has greater process flexibility to treat wastewater and leachate (Lim et al., 2014; Mojiri et al., 2014). This treatment is highly recommended as a costeffective eco-friendly green technology. As shown in Table 1, the SBR with high efficiency in COD, TSS, and $\mathrm{BOD}_{5}$ removal has been employed for POME treatment in previous studies. Moreover, the SBR with activated sludge has been used frequently in a laboratory scale for POME aerobic treatment (Chin et al., 1987; Ma and Ong, 1988; Chin et al., 2013; Chou et al., 2016). Although the efficiency of the SBR method is close to DOE standards, operational cost, activated sludge requirement, and extended period of treatment are drawbacks of this system for POME treatment (Chan et al., 2011). Therefore, a cost-effective and fast method is necessary to improve removal efficiency of aerobic SBR system.

The raw POME, acidic media with a temperature of $80^{\circ} \mathrm{C}-90^{\circ} \mathrm{C}$ (Chin et al., 2013), will cause low content of microbial population. However, the low biodegradability of raw POME makes the digestion process longer and decreases pollutant removal efficiency (Oswal et al., 2002). Zahrim et al. (2009) indicated that the environmental adaptation of microorganisms supplied from activated sludge is a time-consuming process with an average of 60 days. Moreover, low efficiency and high energy consumption were reported when extending the period of treatment (Fun et al., 2007; Vijayaraghavan et al., 2007; Chou et al., 
TABLE 1. EFFECTIVENESS OF THE SBR TREATMENT FOR POME

\begin{tabular}{|c|c|c|c|c|c|c|}
\hline Parameters & $\begin{array}{c}\text { Fu } \\
(2007)\end{array}$ & $\begin{array}{c}\text { Chin and Ma } \\
\text { (1987) }\end{array}$ & $\begin{array}{l}\text { Zahrim et al. } \\
\text { (2009) }\end{array}$ & $\begin{array}{l}\text { Chan } \\
(2010)\end{array}$ & $\begin{array}{l}\text { Chan et al. } \\
\text { (2011) }\end{array}$ & $\begin{array}{c}\text { Chou et al. } \\
\text { (2016) }\end{array}$ \\
\hline Post-treatment & $\begin{array}{c}\text { SBR } \\
\text { activated } \\
\text { sludge }\end{array}$ & $\begin{array}{c}\text { SBR } \\
\text { activated } \\
\text { sludge }\end{array}$ & $\begin{array}{c}\text { SBR } \\
\text { activated } \\
\text { sludge }\end{array}$ & $\begin{array}{c}\text { SBR } \\
\text { activated } \\
\text { sludge }\end{array}$ & $\begin{array}{c}\text { SBR } \\
\text { activated } \\
\text { sludge }\end{array}$ & $\begin{array}{c}\text { SBR } \\
\text { activated } \\
\text { sludge* }^{*}\end{array}$ \\
\hline Pre-treatment & $\begin{array}{l}\text { Anaerobic } \\
\text { digested }\end{array}$ & $\begin{array}{l}\text { Adsorbent } \\
\text { pre-treated }\end{array}$ & $\begin{array}{l}\text { Anaerobic } \\
\text { digested }\end{array}$ & $\begin{array}{l}\text { Anaerobic } \\
\text { digested }\end{array}$ & $\begin{array}{c}\text { Anaerobic } \\
\text { digested }\end{array}$ & $\begin{array}{c}\text { Anaerobic } \\
\text { digested }\end{array}$ \\
\hline $\begin{array}{l}\text { Influent COD } \\
\left(\mathrm{mg} \mathrm{litre}^{-1}\right)\end{array}$ & - & 1550 & 1141 & 13650 & 13532 & 10030 \\
\hline $\begin{array}{l}\text { Influent } \mathrm{BOD}_{5} \\
\left(\mathrm{mg} \text { litre }^{-1}\right)\end{array}$ & - & 700 & - & 1355 & 1355 & - \\
\hline Biodegradability & - & 0.45 & - & 0.1 & 0.1 & - \\
\hline COD removal $(\%)$ & 82 & $31-50$ & 70 & $95-96$ & $63-86$ & $75-93$ \\
\hline $\mathrm{BOD}_{5}$ removal $(\%)$ & - & $50-70$ & - & $97-98$ & $65-87$ & - \\
\hline TSS removal $(\%)$ & 62 & - & - & $98-99$ & $79.2-89.1$ & $81-95$ \\
\hline Colour removal $(\%)$ & - & 50 & 41 & - & - & - \\
\hline Temperature $\left({ }^{\circ} \mathrm{C}\right)$ & - & 42 & - & 28 & 50 & 30 \\
\hline $\mathrm{pH}$ & - & - & $7.7-8.3$ & 7.4 & 7.4 & 7.7 \\
\hline Treatment time & 14 days & 25 days & 60 days & 30 days & $>11$ days & 7.2-18 days \\
\hline
\end{tabular}

Note: *Equal inoculum used as activated sludge.

SBR - sequencing batch reactor; COD - chemical oxygen demand; BOD - biochemical oxygen demand; TSS - total suspended solids; POME - palm oil mill effluent.

2016). Many studies reported that a cost-effective natural adsorbent can be used for enhancing the efficiency of POME decontamination and biological treatment of domestic wastewater (DWW) (Aziz et al., 2011b; 2012; Ismail et al., 2013). The combination of municipal wastewater for enhancing microbial degradation of pollutants, such as $\mathrm{BOD}_{5}, \mathrm{COD}$, TSS and AN, is reported frequently for landfill leachate (Mojiri et al., 2014; Aziz et al., 2011a, b). The POME is a non-toxic agricultural effluent with an extremely high concentration of $\mathrm{BOD}_{5}, \mathrm{COD}$, TSS and colour and low concentration of microbial community. Therefore, municipal or DWW as a low cost material with high microbial source can be used for the treatment of POME. However, a gap of knowledge can still be founded in the literature, particularly to decrease time and cost of POME treatment in SBR system as well as activated sludge requirement (Mansor et al., 2017).

The aim of this study is to develop a fast method to treat POME and improve removal efficiency of aerobic SBR technique. The DWW and zeolite were employed as an available microbial source and new adsorbent, respectively to enhance the SBR treatment process. To achieve a high efficiency of aeration, a new aeration system was developed for the SBR through a couple bulb bottom with opposite direction of aeration. In this reactor, the couple bottom aeration was employed for both mixer and oxygen supplier. The removal of COD, BOD, TSS, AN and colour were measured to evaluate removal efficiency of the suggested technique. The central composite design (CCD) and response surface methodology (RSM) were used to elucidate response surface and optimise the independent variables including contact time, aeration rate and DWW/POME ratio, as well as their dependent variables.

\section{MATERIALS AND METHODS}

\section{POME Sampling}

In the present study, eight raw POME samples were collected during 15 October 2014 to 18 May 2015 from an anaerobically ponding treatment system of United Oil Palm (UOP) located at $100^{\circ} 30^{\prime} 27.90^{\prime \prime} \mathrm{E}$ and $5^{\circ} 9^{\prime} 13.63^{\prime \prime}$ N. As shown in Figure 1, the pond number 8 which is located at the end of the POME treatment system (before algae pond), was selected for the data sampling. The collected samples were transported to a cooling room with temperatures of $4^{\circ} \mathrm{C}$ to minimise the chemical and biological reactions. The characteristics of the collected POME are listed in Table 2. 


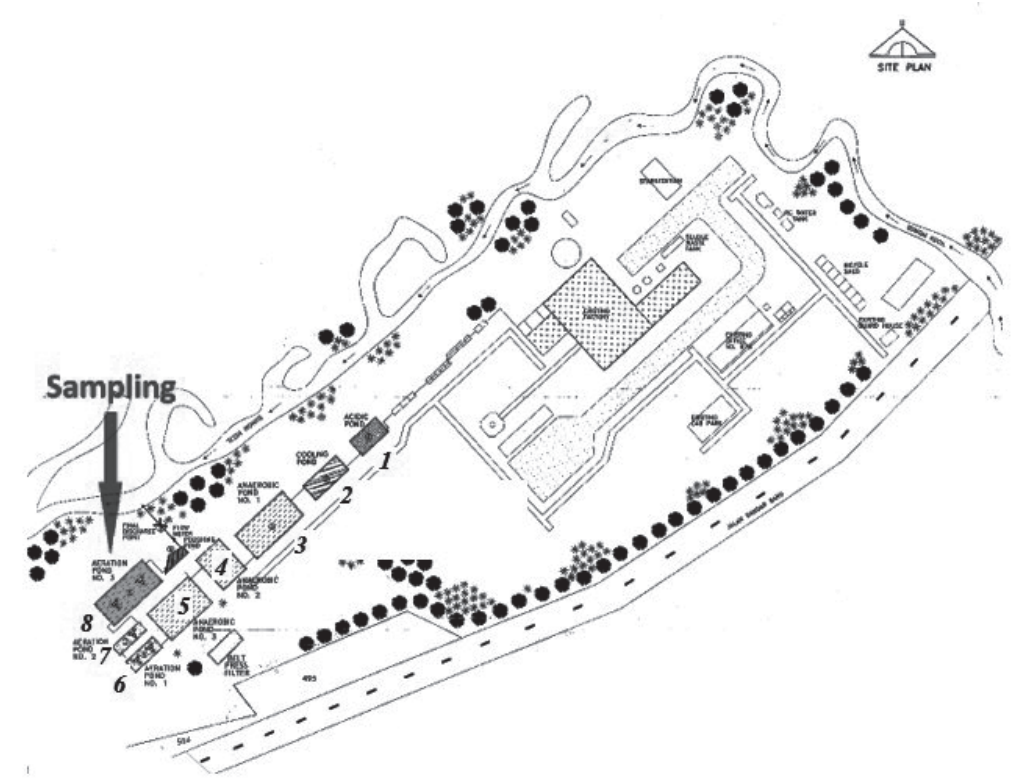

Figure 1. Anaerobically treated palm oil mill effluent (POME) sampling (pond number).

TABLE 2. CHARACTERISTICS OF POME, DWW AND STANDARD DISCHARGE LIMIT FOR POME

\begin{tabular}{|c|c|c|c|c|c|c|c|}
\hline \multirow{2}{*}{ Parameters } & \multicolumn{3}{|c|}{ POME } & \multicolumn{3}{|c|}{ DWW } & \multirow{2}{*}{$\begin{array}{l}\text { Standard } \\
\text { discharge limit } \\
\text { for POME }\end{array}$} \\
\hline & Min & Max & Ave & Min & Max & Ave & \\
\hline Temperature & 28.5 & 32 & 30.2 & 29 & 31 & 29.3 & 45.0 \\
\hline $\mathrm{pH}$ & 6.7 & 7.6 & 7.32 & 6.6 & 7 & 6.8 & $5.0-9.0$ \\
\hline Total suspended solids (mg litre ${ }^{-1}$ ) & 2890 & 4570 & 4310 & 4.7 & 5.2 & 5.0 & 200.0 \\
\hline Colour (ADMI) & 1750 & 3350 & 2550 & 68 & 75 & 77 & 100.0 \\
\hline $\mathrm{BOD}_{5}\left(\mathrm{mg}\right.$ litre $\left.^{-1}\right)$ & 995 & 1685 & 1230 & 91 & 102 & 100 & 20.0 \\
\hline COD (mg litre $\left.{ }^{-1}\right)$ & 8225 & 13555 & 11090 & 225 & 260 & 240 & $50^{*}$ \\
\hline $\mathrm{BOD}_{5} / \mathrm{COD}$ & 0.1 & 0.116 & 0.11 & 0.38 & 0.46 & 0.41 & - \\
\hline Total phosphorus (mg litre ${ }^{-1}$ ) & 97 & 153 & 124.5 & 7.2 & 9.8 & 9 & - \\
\hline Ammonia nitrogen (AN) (mg litre $\left.{ }^{-1}\right)$ & 82 & 107 & 94.5 & 11 & 21 & 14 & 10.0 \\
\hline Total nitrogen (mg litre $\left.{ }^{-1}\right)$ & 275 & 440 & 360 & 16.8 & 30.5 & 22.9 & 10.0 \\
\hline Total iron $\left(\mathrm{mg}\right.$ litre $\left.^{-1}\right)$ & 0.34 & 0.55 & 0.4 & 1.39 & 1.55 & 1.4 & - \\
\hline Total manganese (mg litre ${ }^{-1}$ ) & 135 & 153 & 146.5 & 5.5 & 5.8 & 5.7 & - \\
\hline Total calcium (mg litre ${ }^{-1}$ ) & 38 & 43 & 40.9 & 18.5 & 23.2 & 22.1 & - \\
\hline Turbidity (NTU) & 4362 & 790 & 6012 & 8 & 13.3 & 11.9 & - \\
\hline
\end{tabular}

Note: *Requirement set by the Malaysia Sewage and Industrial Effluent Discharge Standard, Deparment of Environment (DOE). POME - palm oil mill effluent; DWW - domestic wastewater; BOD - biochemical oxygen demand; Ave - average; ADMI - American Dye Manufacturers Institut; COD - chemical oxygen demand; NTU - nephelometric turbidity units.

\section{Domestic Wastewater (DWW) Sampling}

DWW was collected from the Indah Water Konsortium Regional Treatment Plant located at $100^{\circ} 27^{\prime} 10.8^{\prime \prime} \mathrm{E}$ and $5^{\circ} 20^{\prime} 25.5^{\prime \prime} \mathrm{N}$. The samples were directly send to a cool room $\left(4^{\circ} \mathrm{C}\right)$ and kept in a white high density polyethylene (HDPE) container. Before using the samples, they were shaken until their temperature reached the laboratory temperature $\left(31.2^{\circ} \mathrm{C}\right)$. The characteristics of DWW and POME standards discharge suggested by DOE is shown in Table 2.

\section{Reactor Characteristics}

In this research, a new SBR (new-SBR) was developed to improved removal efficiency of traditional reactors. The new-SBR was composed of a transparent column and a plexiglas plate to observe the settling process. To achieve a high efficiency of aeration, a novel system was developed for aeration of reactors through a couple bulb bottom with opposite direction of aeration. In the new-SBR, the couple bottom aeration was used for both mixer and oxygen supplier (Figure 2). No 
need for any mixing system can be considered as a novelty of the new-SBR. Twenty of the new-SBR reactor were created for experiments and they run at the same time under the same environmental conditions. Aeration was prepared using two air pumps (air volume, 60 litre $\mathrm{min}^{-1}$; LP-60A Model, Yasunaga, Air Pump Inc., China) where each pump was connected to 10 new-SBR using a valve. To adjust the flow rate, a manual air flow meter was used. Easy application and can be simultaneously run is the attraction of this new system.

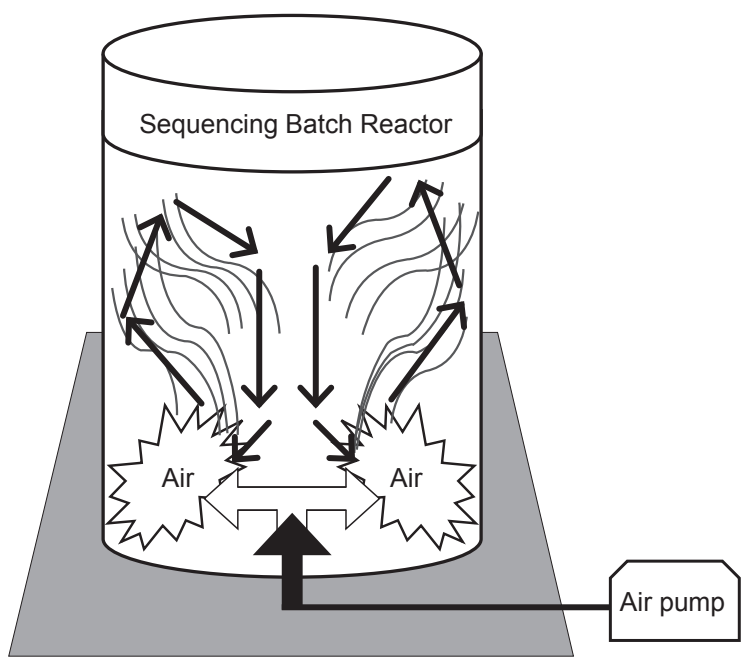

Figure 2. New-sequencing batch reactor without a mixer system.

\section{Zeolite Preparation}

In the present study, powdered natural zeolite (PNZ) was used as an adsorbent in the new-SBR. The sieves No. 100 and 200 were chosen for all experiment to provide the suitable powder PNZ in range of 75-150 $\mu \mathrm{m}$ (Mojiri et al., 2014). To prepare zeolite for each treatment, at first, $15 \mathrm{~g}$ litre $^{-1}$ of zeolite was dried in the oven for $24 \mathrm{hr}$ at $105 \pm 2^{\circ} \mathrm{C}$. Table 3 shows the features of the PNZ with the autosorb test. Figure 3 and Table 4 indicate the results of the $\mathrm{X}$-ray fluorescence (XRF) and scanning electron microscope (SEM) analyses for PNZ, respectively. The SEM affords a magnified 3D view of natural zeolite surface with a great depth of focus. The SEM images from the surface of zeolite with magnified of 10000 and 20000 is shown in Figure 3. The pores on the surface of zeolite is a good reason for low density of zeolite and indicates that it is a suitable adsorbent with high-quality.

The energy dispersive X-ray spectroscopy (EDS) was carried out to illustrate the structural compound and elements existing in the zeolite. Table 5 shows the weight and atomic percentage of natural zeolite elements before treatment. The result indicates that zeolite is an aluminosilicate mineral with a low carbon content in its structure. Furthermore, the $\mathrm{Si} / \mathrm{Al}$ with a value of 3.41
$(19.52 / 5.71=3.41$, Table 5) is within the range of 2.7 to 5.3 , therefore the natural zeolite applied in this study can be considered as Clinoptilolite (Kesraoui-Okui et al., 1994). The percentages of the different structural elements of the zeolite were also determined from the spectrum diagram in Figure 4. The spectrum of the natural zeolite shows sharp peaks without shoulders and separated elements in a thin basement line. The results indicate that the carbon content in the zeolite is very low with a little impurity of unknown elements.

\section{TABLE 3. POWDERED NATURAL ZEOLITE} CHARACTERISTICS

\begin{tabular}{lcc}
\hline Parameters & Unit & Value \\
\hline Single point & $\mathrm{m}^{2} \mathrm{~g}^{-1}$ & 23.76 \\
Multi point BET & $\mathrm{m}^{2} \mathrm{~g}^{-1}$ & 23.88 \\
Langmuir surface area & $\mathrm{m}^{2} \mathrm{~g}^{-1}$ & 36.10 \\
T method micro pore surface area & $\mathrm{m}^{2} \mathrm{~g}^{-1}$ & 10.03 \\
T method external surface area & $\mathrm{m}^{2} \mathrm{~g}^{-1}$ & 13.85 \\
Total pore volume for pore & $\mathrm{ml} \mathrm{g}^{-1}$ & 0.0052 \\
\hline
\end{tabular}

Note: BET - Brunauer-Emmet-Teller.

TABLE 4. RESULTS OF X-RAY FLUORESCENCE (XRF) FOR ZEOLITE

\begin{tabular}{lc}
\hline Compounds & Percentage \\
\hline Silicon dioxide $\left(\mathrm{SiO}_{2}\right)$ & 73.30 \\
Aluminium oxide $\left(\mathrm{Al}_{2} \mathrm{O}_{3}\right)$ & 16.69 \\
Calcium oxide $(\mathrm{CaO})$ & 2.59 \\
Potassium oxide $\left(\mathrm{K}_{2} \mathrm{O}\right)$ & 2.54 \\
Iron $(\mathrm{III})$ oxide $\left(\mathrm{Fe}_{2} \mathrm{O}_{3}\right)$ & 2.17 \\
Sodium oxide $\left(\mathrm{Na}_{2} \mathrm{O}\right)$ & 0.52 \\
Magnesium oxide $(\mathrm{MgO})$ & 1.53 \\
Titanium dioxide $(\mathrm{TiO})$ & 0.24 \\
Manganese oxide $(\mathrm{MnO})$ & 0.10 \\
Others & 0.32
\end{tabular}

TABLE 5. WEIGHT AND THE ATOMIC PERCENTAGE OF NATURAL ZEOLITE ELEMENTS (SEM-EDS)

\begin{tabular}{lcc}
\hline Element & $\begin{array}{c}\text { Weight } \% \text { before } \\
\text { treatment }\end{array}$ & $\begin{array}{c}\text { Atomic \% before } \\
\text { treatment }\end{array}$ \\
\hline Oxygen $(\mathrm{O})$ & $56.72 \pm 0.72$ & 66.94 \\
Silicon $(\mathrm{Si})$ & $29.04 \pm 0.67$ & 19.52 \\
Carbon $(\mathrm{C})$ & $3.92 \pm 0.44$ & 6.16 \\
Aluminium $(\mathrm{Al})$ & $8.16 \pm 0.42$ & 5.71 \\
Magnesium $(\mathrm{Mg})$ & $2.15 \pm 0.26$ & 1.67 \\
\hline Total & 100.00 & 100.00 \\
\hline
\end{tabular}

Note: SEM - scanning electron microscope; EDS - energy dispersive $\mathrm{X}$-ray spectroscopy.

\section{Analytical Method}

In this study, the standard methods of the American Public Health Association (APHA) 2017 were used for all tests of wastewater and water. A Multiprobe system of YSI 556 was used to record the total dissolved solids (TDS, mg litre $\left.^{-1}\right), \mathrm{pH}$, and dissolved oxygen (DO, mg litre ${ }^{-1}$. 
A spectrophotometer (DR 2800, $2100 \mathrm{~N}$ and DR $2500 \mathrm{HACH}$ ) was used to determine the suspended solids (mg litre ${ }^{-1}$, contents of colour (Pt. Co.), total phosphorus (mg litre $\left.{ }^{-1}\right)$, total nitrogen

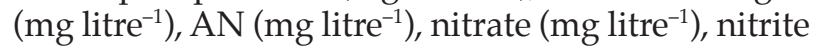
$\left(\mathrm{mg}\right.$ litre $\left.^{-1}\right)$, and COD (mg litre $\left.{ }^{-1}\right)$. The inductively coupled plasma (ICP Varian, OES 715) was utilised to determine the concentration of metallic elements, such as iron ( $\mathrm{Fe}, \mathrm{mg}$ litre $\left.^{-1}\right)$, magnesium $\left(\mathrm{Mg}, \mathrm{mg}\right.$ litre $\left.^{-1}\right)$, and calcium $\left(\mathrm{CaCO}_{3}, \mathrm{mg}\right.$ litre $\left.^{-1}\right)$.

\section{The New-SBR Operation}

The new-SBR system involves the following phases: fill, react, settling, and draw and idle. The durations of fill and mix (20 min), settling (156 min), and draw and idle ( $8 \mathrm{~min}$ ) were considered to be fixed in all of the experiments. Various aeration rates of 0.5 , 4 and 7.5 litres $\mathrm{min}^{-1}$; different duration for contact times ( $2 \mathrm{hr}, 12 \mathrm{hr}$ and $22 \mathrm{hr}$ ); and different rates of DWW to POME (DWW/POME) such as 20\%, 50\%, and $80 \%$ were applied to evaluate treatment of the new-SBR. Twenty Plexiglas beakers with a working volume of 1 litre and a final volume of $1700 \mathrm{ml}$

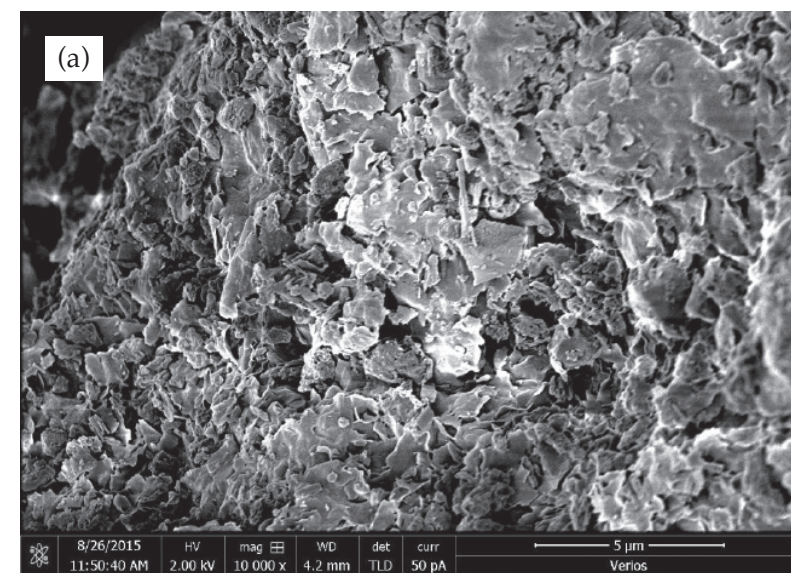

were used to avoid errors caused by operational or environmental factors. As mentioned, the developed new-SBR was used in all of the 20 reactors. Based on the preliminary experiments and before aeration, $15 \mathrm{~g} \mathrm{litre}^{-1}$ PNZ was used in each new-SBR for the adsorption of pollutants. The pollution parameters such as BOD, TSS, COD, AN and colour were measured after and before the treatment process. The Equation (1) was used to determine the removal efficiency of the new-SBR systems:

$$
\operatorname{Removal}(\%)=\frac{C_{i}-C_{f}}{C_{i}} \times 100
$$

Equation (1)

where $C_{i}$ is initial and $C_{f}$ is final concentration of pollution parameters.

\section{Data Analysis and Experimental Design}

To determine the optimum conditions for the independent parameters and demonstrate the nature of the response surface in the experimental design, both CCD and RSM were utilised in this study. The Design Expert software was used to estimated CCD

Figure 3. Scanning electron microscope (SEM) images from the surface of zeolite with magnified of (a) 10000 and (b) 20000.

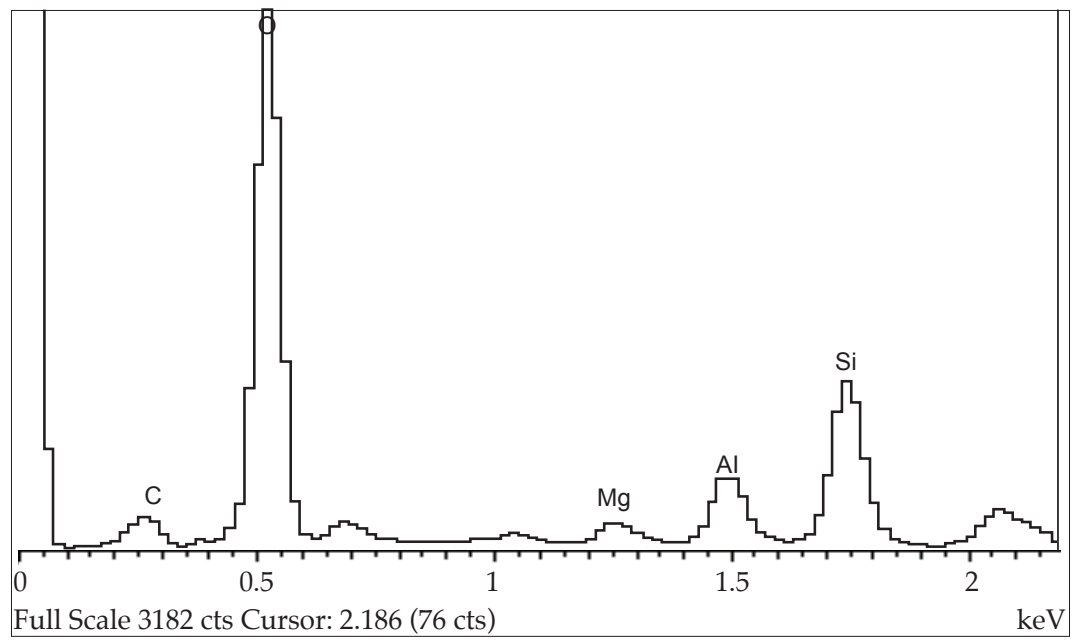

Figure 4. Natural zeolite spectrum (energy dispersive X-ray spectroscopy of the plotted area) before treatment. 
and RSM. The polynomial equation with secondorder, as expressed in Equation (2), was selected to evaluate the system performance:

$$
\begin{aligned}
Y= & \beta_{0}+\sum_{i=1}^{k} \beta_{i} X_{i}+\sum_{i=1}^{k} \beta_{i i} X^{2} \\
& +\sum_{i i<j}^{k} \sum_{j}^{k} \beta_{i j} X_{i} X_{j}+\cdots+e
\end{aligned}
$$

Equation (2)

where $Y$ represents the response; the variables are represented by $X_{i}$ and $X_{j} ; \beta_{0}$ represents a constant coefficient; numbers of studied factors are represented by $k$; the linear quadratic and secondorder coefficients are represented by $\beta_{i^{\prime}} \beta_{i j^{\prime}}$ and $\beta_{i i}$; and error is represented by $e$. The provided results were evaluated through analysis of variance (ANOVA) technique. As mentioned, $k$ is the number of variables; thus, $k^{2}$ is equal to the factorial point supported by a centre point and $2 k$ axial points. To fit the second-order polynomial models and calculate the experimental error, six replicates were used at the central points. Three levels were chosen to evaluate the three operating variables namely, high $(+1)$, medium (0), and low (-1). The RSM and CCD were applied to determine the best value of responses and for optimising the appropriate circumstances of the operation. The contact time $(2 \mathrm{hr}, 12 \mathrm{hr}$ and $22 \mathrm{hr})$, aeration rate $\left(0.5,4\right.$ and 7.5 litres $\left.\mathrm{min}^{-1}\right)$, and DWW / POME ratio $(20 \%, 50 \%$, and $80 \%$; V / V) were chosen as independent variables and their response (COD, BOD, TSS, AN and colour) were selected as dependent variables in this study (Table 6).

\section{RESULTS AND DISCUSSION}

\section{COD, AN, Colour and BOD Removal}

Table 2 indicates the maximum, minimum and average values of measured parameters of POME, DWW and standard discharge limit suggested by DOE. Understanding the characteristics of pollutants is crucial in the selection of treatment method. According to Ho and Tan (1983), centrifuge technique (depending on gravity force and operation time) can reduce the total amount of POME pollutants, such as TSS, $\mathrm{BOD}_{5}$, COD, total nitrogen and AN. Consequently, POME contains high concentrations of real colour particles. Therefore, the parameters of BOD, COD, AN and colour are chosen for discussion in this section. The POME contains high concentrations of TSS (4310 mg litre ${ }^{-1}$ ) COD (11 090 mg litre ${ }^{-1}$ ) and high intensive colour (2550 Pt. Co.). The value of $\mathrm{BOD}_{5}\left(1230 \mathrm{mg}\right.$ litre $\left.{ }^{-1}\right)$ and $\mathrm{BOD}_{5} / \mathrm{COD}$ (0.11) show the low biodegradability in the POME (Table 2). Metcalf and Eddy (2014) reported that for a wastewater with biodegradability index $\left(\mathrm{BOD}_{5} /\right.$ COD ratio) bigger than 0.5 , the wastewater can be considered for biological treatment. These results indicated that the anaerobic treatment of POME still contains high pollution and this method can hardly reach to the standard level of discharge defined by DOE. Therefore, an appropriate post-treatment is essential in order to meet the DOE levels. Previous

\begin{tabular}{|c|c|c|c|c|c|c|c|c|c|}
\hline $\begin{array}{l}\text { Run } \\
\text { No. }\end{array}$ & $\begin{array}{c}\text { Aeration* } \\
\text { (litre } \text { min }^{-1} \text { ) }\end{array}$ & $\begin{array}{c}\text { Aeration } \\
\text { duration } \\
\text { (hr) }\end{array}$ & $\begin{array}{c}\text { DWW/ } \\
\text { POME } \\
(\%)\end{array}$ & $\begin{array}{c}\text { TSS } \\
\text { removal } \\
(\%)\end{array}$ & $\begin{array}{c}\text { COD } \\
\text { removal } \\
(\%)\end{array}$ & $\begin{array}{c}\text { BOD } \\
\text { removal } \\
(\%)\end{array}$ & $\begin{array}{c}\text { Colour } \\
\text { removal } \\
(\%)\end{array}$ & $\begin{array}{c}\text { Ammonia } \\
\text { removal } \\
(\%)\end{array}$ & BOD/COD \\
\hline 1 & 0.5 & 2 & 20 & 98.21 & 95.91 & 90.16 & 64.66 & 98.2 & 0.94 \\
\hline 2 & 4.0 & 22 & 50 & 98.37 & 97.07 & 91.44 & 73.05 & 98.09 & 0.94 \\
\hline 3 & 4.0 & 12 & 50 & 96.61 & 96.67 & 90.56 & 71.88 & 98.09 & 0.94 \\
\hline 4 & 7.5 & 12 & 50 & 96.14 & 96.35 & 89.47 & 66.70 & 98.20 & 0.93 \\
\hline 5 & 0.5 & 22 & 80 & 98.95 & 98.31 & 90.08 & 81.64 & 96.93 & 0.92 \\
\hline 6 & 7.5 & 22 & 20 & 98.86 & 95.92 & 89.98 & 69.52 & 97.98 & 0.94 \\
\hline 7 & 4.0 & 12 & 50 & 96.79 & 96.48 & 90.03 & 65.84 & 97.88 & 0.93 \\
\hline 8 & 4.0 & 12 & 80 & 98.90 & 98.23 & 89.67 & 80.43 & 98.09 & 0.91 \\
\hline 9 & 4.0 & 12 & 50 & 98.23 & 96.40 & 89.10 & 67.17 & 98.29 & 0.92 \\
\hline 10 & 0.5 & 2 & 80 & 95.87 & 96.32 & 89.51 & 59.60 & 97.98 & 0.93 \\
\hline 11 & 7.5 & 2 & 20 & 96.31 & 95.34 & 90.01 & 56.94 & 97.67 & 0.94 \\
\hline 12 & 7.5 & 22 & 80 & 98.32 & 98.10 & 90.69 & 75.25 & 98.30 & 0.92 \\
\hline 13 & 0.5 & 22 & 20 & 97.91 & 95.70 & 89.30 & 57.52 & 97.21 & 0.93 \\
\hline 14 & 4.0 & 12 & 50 & 96.12 & 96.37 & 88.79 & 64.70 & 98.20 & 0.92 \\
\hline 15 & 7.5 & 2 & 80 & 98.32 & 98.07 & 90.29 & 80.70 & 98.20 & 0.92 \\
\hline 16 & 0.5 & 12 & 50 & 95.47 & 96.33 & 89.46 & 62.66 & 97.67 & 0.93 \\
\hline 17 & 4.0 & 12 & 20 & 97.74 & 97.85 & 89.52 & 79.05 & 97.98 & 0.91 \\
\hline 18 & 4.0 & 2 & 50 & 97.88 & 96.50 & 89.20 & 67.25 & 96.19 & 0.92 \\
\hline 19 & 4.0 & 12 & 50 & 97.23 & 96.74 & 88.95 & 70.39 & 97.67 & 0.92 \\
\hline 20 & 4.0 & 12 & 50 & 97.09 & 96.91 & 89.57 & 74.15 & 98.09 & 0.92 \\
\hline
\end{tabular}

TABLE 6. EXPERIMENTAL VARIABLES AND RESULTS FOR THE NEW- SEQUENCING BATCH REACTOR (SBR)

Note: *Before aeration, $15 \mathrm{~g}$ litre ${ }^{-1}$ zeolite (based on the volume of POME) was used in each new-SBR.

DWW - domestic wastewater; POME - palm oil mill effluent; TSS - total suspended solids; BOD - biochemical oxygen demand; COD - chemical oxygen demand. 
studies indicated that high concentration of $\mathrm{COD}, \mathrm{NH}_{3}-\mathrm{N}$ and low biodegradability index decreased the efficiency of SBR (Aziz et al., 2011; Kamarudzaman et al., 2011). However, adding absorbent into the SBR can efficiently remove pollutants at an improved rate (Neczaj et al., 2007).

In this study, the PNZ and wastewater were used as a cost-effective biological co-treatment materials to improve the efficiency of the newSBR and to decrease the environmental impacts of discharging caused by POME. Table 6 shows the removal efficiency of the new-SBR for the different variable of POME. As mentioned, before aeration and for the adsorption of pollutants, $15 \mathrm{~g}$ litre $\mathrm{e}^{-1} \mathrm{PNZ}$ was used in the new-SBR. The results are reported based on different aeration rate, aeration duration and percentage of DWW to POME (DWW / POME). As shown in Table 6, the variation of COD removal is between $95.34 \%$ and $98.31 \%$. The highest removal of COD $(98.31 \%)$ was achieved under the contact time of $22 \mathrm{hr}$, aeration rate of 0.5 litre $\mathrm{min}^{-1}$ and DWW/POME ratio of $80 \%$. The minimum COD removal $\left(95.34 \%\right.$ ) was at 7.5 litres $\mathrm{min}^{-1}$ aeration rate, $2 \mathrm{hr}$ contact time, and 20\% of DWW/POME. The 2D contour plot and 3D response surface plot for COD removal are illustrated in Figure 5. An optimal COD removal $(98.362 \%)$ was provided at the aeration rate of 2.930 litres $\mathrm{min}^{-1}$, contact time of $13.617 \mathrm{hr}$, and DWW/POME ratio of $78.476 \%$. The results are consistent with those in previous studies (Aziz et al., 2011; Mojiri et al., 2014).

In the conventional biological treatment of wastewater, the AN is a significant inhibitor compound. Ammonia decreases biodegradability ratio and prohibits microbial growth. Furthermore, eutrophication accelerates and DO decreases with increasing concentration of $\mathrm{AN}$ ( $\mathrm{Li}$ et al., 1999). Aziz et al. (2013) showed that most AN can be removed biologically. A combination of biological degradation and zeolite adsorption was used in the new-SBR for AN removal through microbial biofilm formation on the surface of the zeolite. As shown in Table 6, the ammonia removal increased from $96.19 \%-98.30 \%$. The lowest ammonia removal occurred under contact time of $2.0 \mathrm{hr}$, the aeration rate of 4.0 litres $\mathrm{min}^{-1}$, and DWW/POME ratio of $50 \%$. The highest ammonia removal was observed under the following conditions, 7.5 litres $\mathrm{min}^{-1}$ aeration rate, $22 \mathrm{hr}$ contact time, and $80 \% \mathrm{DWW} /$ POME.

Figure 6 shows the 3D response surface plot for AN removal. The results showed that the new-SBR system can reach to the optimum removal efficiency of ammonia $(98.33 \%)$ at a contact time of $18.32 \mathrm{hr}$, an aeration rate of 4.81 litres $\mathrm{min}^{-1}$, and DWW/ POME ratio of $76.97 \%$. This finding means that the optimal desirable operation can be achieved through POME treatment in the new-SBR system under the aforementioned operation conditions.
In medium strength wastewater, approximately $75 \%$ of suspended solids and $40 \%$ of filterable solids are the organic materials (Metcalf and Eddy, 2014). The major organic compounds present in wastewater, detergents, carbohydrates, greases and oil, and proteins. Drinan and Spellman (2012) reported that around 30\% of the organic compounds are not biodegradable. The POME is a high-strength colloidal agroindustry effluent with a high value of TSS (4310 mg litre ${ }^{-1}$, Table 2), then a chemical adsorption is necessary to remove TSS. Chemical adsorption plays a supplementary role in microbial growth and adsorption, and zeolite is a promising adsorbent for suspended solids. According to Montalvo et al. (2012), a 3D structure of zeolite presents a high specific surface area (SSA). Erdem et al. (2004) reported that the zeolite with $41.5 \%$ porosity, $2.27 \mathrm{~g} \mathrm{~cm}^{-3}$ appearance density and 1.32 $\mathrm{g} \mathrm{cm}^{-3}$ weight per unit volume is recognised as a suitable adsorbent with high hollow micropores and macropores. These properties provide a high surface for the monolayer adsorption of organic pollutants and a cation exchangeable capacity that can act as a capable chemical adsorption of macro and micro elements. Table 6 indicates that the efficiency of the new-SBR with zeolite and DWW in TSS removal increased from $95.47 \%$ (contact time of $12 \mathrm{hr}$, aeration flow of 0.5 litre $\mathrm{min}^{-1}$, and $\mathrm{DWW} / \mathrm{POME}$ ratio of $50 \%$ ) to $98.95 \%$ (contact time of $22 \mathrm{hr}$, aeration rate of 0.5 litre $\mathrm{min}^{-1}$ and DWW / POME ratio of $80 \%$ ).

TSS removal and biodegradability index $\left(\mathrm{BOD}_{5} /\right.$ COD ratio) are bigger than $95 \%$ and 0.5 , respectively for all cases in Table 6. High $\mathrm{BOD}_{5} / \mathrm{COD}$ increases the percentage of degradation and functions as an acceptable indicator of enhanced TSS removal as an organic pollutant. Therefore, the efficiency of the new-SBR in POME treatment increases by enhancing POME biodegradability. Results of TSS removal indicated that the combination of raw DWW as a microbial biodegradation supplier in the presence of zeolites for coagulation is an effective treatment method for the decontamination of biodegradable and non-biodegradable suspended solids. Figure 7 shows the 2D contour plot and 3D response surface plot for TSS removal. The optimum TSS removal $(99.16 \%)$ was observed at DWW/POME of $22.06 \%$, aeration rate of 5.16 litres $\mathrm{min}^{-1}$ and a contact time of $21.6 \mathrm{hr}$. This result means that the new-SBR system could reach the highest achievable desirability under the aforementioned conditions.

Table 2 shows that collected POME from UOP contained a high intensity of colour (2550 Pt. Co.). According to Liew et al. (2015), colour is a critical pollutant in POME. Several methods have been applied to remove colour such as, the SBR systems (Zahrim et al., 2009), anaerobic reactions (Zhang et al., 2008), banana peel (Mohammed and Chong, 2014), boiler fly ash (Igwe et al., 2010) and activated carbon (Zahrim et al., 2009). The low declorisation efficiency 

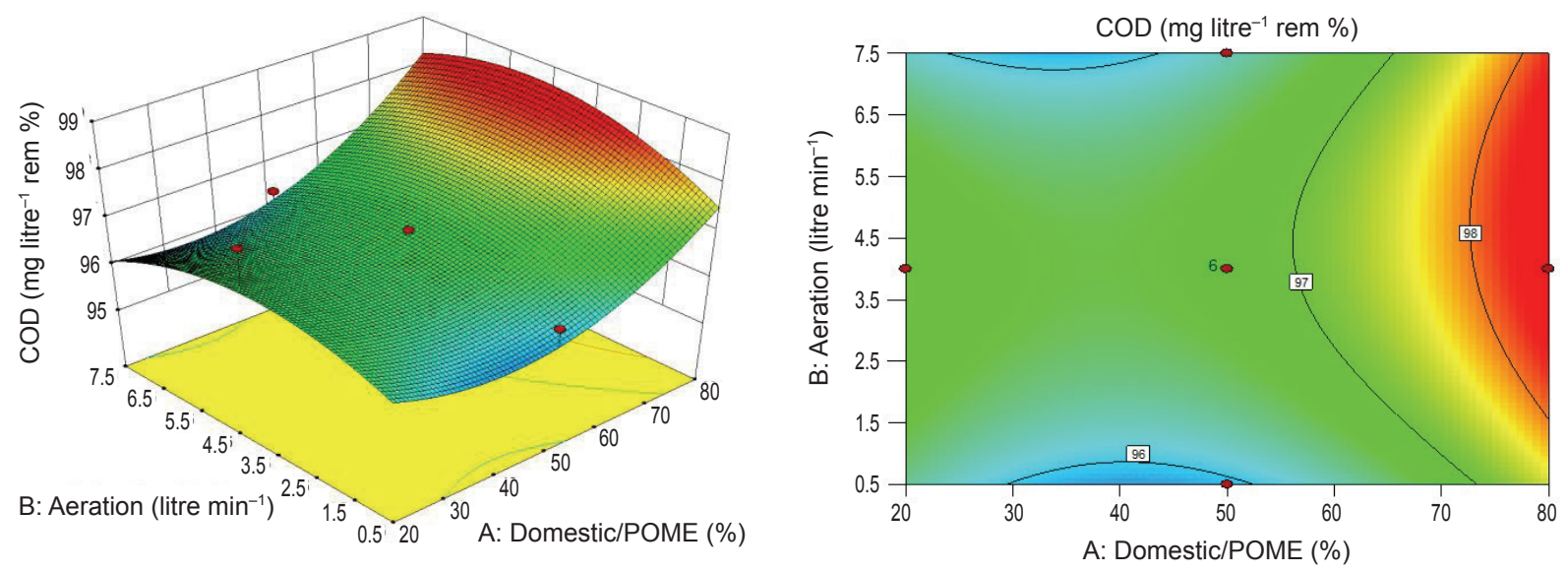

Note: POME - palm oil mill effluent; COD - chemical oxygen demand.

Figure 5. The 3D surface plots and 2D contour plot for COD removal.

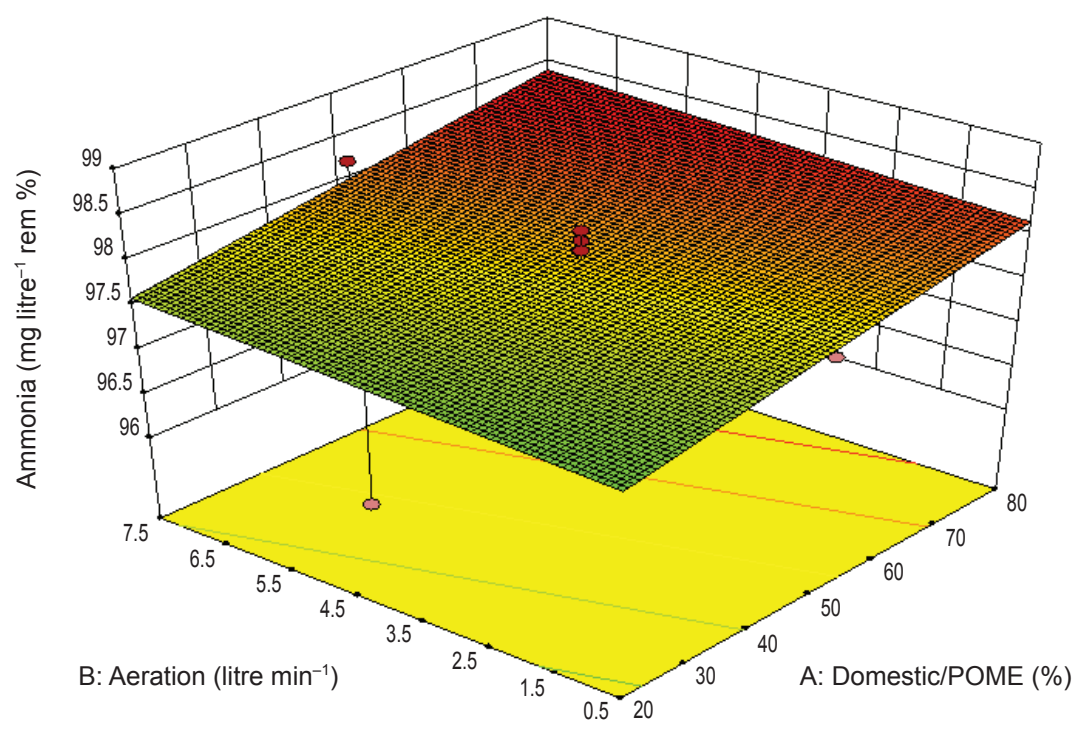

Note: POME - palm oil mill effluent.

Figure 6. The 3D surface plots of ammonia nitrogen (AN) removal.

and high-cost treatments are the two main problems that limit the applications of commonly used methods. The biological and adsorption phenomena are the main factors influencing colour removal. The zeolite contains a high SSA which provides a specific suitable surface for microbial film forming (adsorbing and biodegradation). Micropores and macropores could be considered as suitable spaces for colour particles absorbing. For colour removal of landfill leachate, the aerobic SBR with adsorbent and wastewater as the augmentations was recommended as a cost-effective method (Aziz et al., 2011a). Table 6 illustrates that in the new-SBR system, the minimum and maximum colour removal are $56.94 \%$ (contact time of $2 \mathrm{hr}, \mathrm{DWW} / \mathrm{POME}$ of $20 \%$, and aeration rate of 7.5 litres $\mathrm{min}^{-1}$ ) and $81.64 \%$ (contact time of $22 \mathrm{hr}$, DWW / POME of $80 \%$, and aeration rate of 0.5 litre $\mathrm{min}^{-1}$ ) respectively.
Based on the Brunauer-Emmet-Teller (BET) test, the SSA of zeolite were decreased significantly after treatment process which may illustrate the action of zeolite as a suitable adsorbent. Moreover, the SEMEDX indicates that natural zeolite fully covered by pollutants after the treatment process. Therefore, the suggested new-SBR can be employed as a cost effective declorisation system because of the positive effect of zeolite and DWW that enhances biological treatment. The POME treatment in the new-SBR could reach to optimum colour removal at DWW / POME ratio of $77.296 \%$, aeration rate of 4.298 litres $\mathrm{min}^{-1}$ and contact time of $15.506 \mathrm{hr}$. Under these conditions, optimum decolourisation was observed to be $82.028 \%$.

Estimation of BOD in the wastewater is one of the best methods to determine organic content. Gerardi (2011) showed that reducing oil, fats and 
grease decreases BOD significantly. The BOD adsorption is recognised as particle diffusioncontrolled mechanism and can be used to treat POME. In the new-SBR, the BOD removal varied from $88.79 \%-91.44 \%$ (Table 6). The lowest BOD removal was observed at a DWW/POME of 50\%, contact time of $12 \mathrm{hr}$, and aeration rate of 4 litres $\mathrm{min}^{-1}$ while the highest one occurred at a DWW/ POME of $50 \%$, contact time of $22 \mathrm{hr}$ and aeration rate of 4 litres $\mathrm{min}^{-1}$. The results indicate that there is no significant different between the highest and lowest BOD removal efficiencies (88.79\%-91.44\%). It seems that the presence of DWW even in very low concentration provides high performance of BOD removal. For Run 1 (Table 6), although the DWW is low (DWW/POME $=20 \%$ ), the BOD removal is $90.16 \%$. More researches required to specifying the minimum DWW as augmentation for POME treatment in the aerobic new-SBR system. The duration of aeration is another parameter which directly effects on BOD removal. A comparison between Run 12 and 15 with a same DWW/POME of $80 \%$ and aeration of 7.5 litres $\mathrm{min}^{-1}$ indicates that BOD removal increases from $90.29 \%-90.96 \%$ with increase in the aeration contact time from $2.0-22 \mathrm{hr}$, respectively. Furthermore, a comparison between Run 5 and 12 shows that BOD removal enhances by raising the aeration rate. Therefore, high aeration rate and long contact time did improve BOD removal efficiency through the new-SBR systems. Similar results were reported by Sahu et al. (2009). The RSM and CCD analysis indicate that the optimum removal efficiency of BOD $(90.67 \%)$ was attained at 6.74 litres $\mathrm{min}^{-1}$ aeration rate, $1.99 \mathrm{hr}$ contact time, and $66.39 \%$ DWW / POME ratio.

Microbiological treatment can be determined from biodegradability index (BOD/COD ratio). However, decontamination of wastewater increases with enhancing biodegradability. As shown in Table 2 , by considering the value of $\mathrm{BOD}_{5} / \mathrm{COD}$ as the biodegradability index in POME (0.11) and DWW (0.41), DWW is more biodegradable in comparison with anaerobically treated POME. After treatment of POME in the new-SBR, the results indicate that the ratio of $\mathrm{BOD}_{5} / \mathrm{COD}$ is bigger than 0.9 for all cases (Table 6). It can be concluded the new-SBR with DWW and zeolite as the augmentations was achieved to successfully improve the biodegradability of POME. A 3D surface plots and 2D contour of POME biodegradability is shown in Figure 8. The optimum POME biodegradability was obtained for $12 \mathrm{hr}$ contact time, 4 litres $\mathrm{min}^{-1}$ aeration and the DWW/ POME of $80 \%$.

\section{Evaluation of the New-SBR with Zeolite and DWW}

The aim of this part of the research is to identify the most influenced augmentation for POME treatment in the new-SBR system. As shown in Table 7, several experiments were conducted to evaluate removal efficiency of the new-SBR for TSS, COD, colour and AN. Previous studies reported that augmentation of natural adsorbents can enhance pollutant removal efficiency (Halim et al., 2010; Kalló, 2001; Shavandi et al., 2012). Moreover, Vijayaraghavan et al. (2007) found that microbial communities exert a positive effect on POME treatment. Therefore, different conditions were considered to compare the ability of the new-SBR to improve POME such as 1) the blank new-SBR without any extra material as a case for control, 2) the new-SBR with adding zeolite, 3) the new-SBR with adding DWW and 4) the new-SBR with adding both zeolite and DWW. The experiments were performed under the similar optimum conditions and three replication runs were conducted to provide actual assessment.
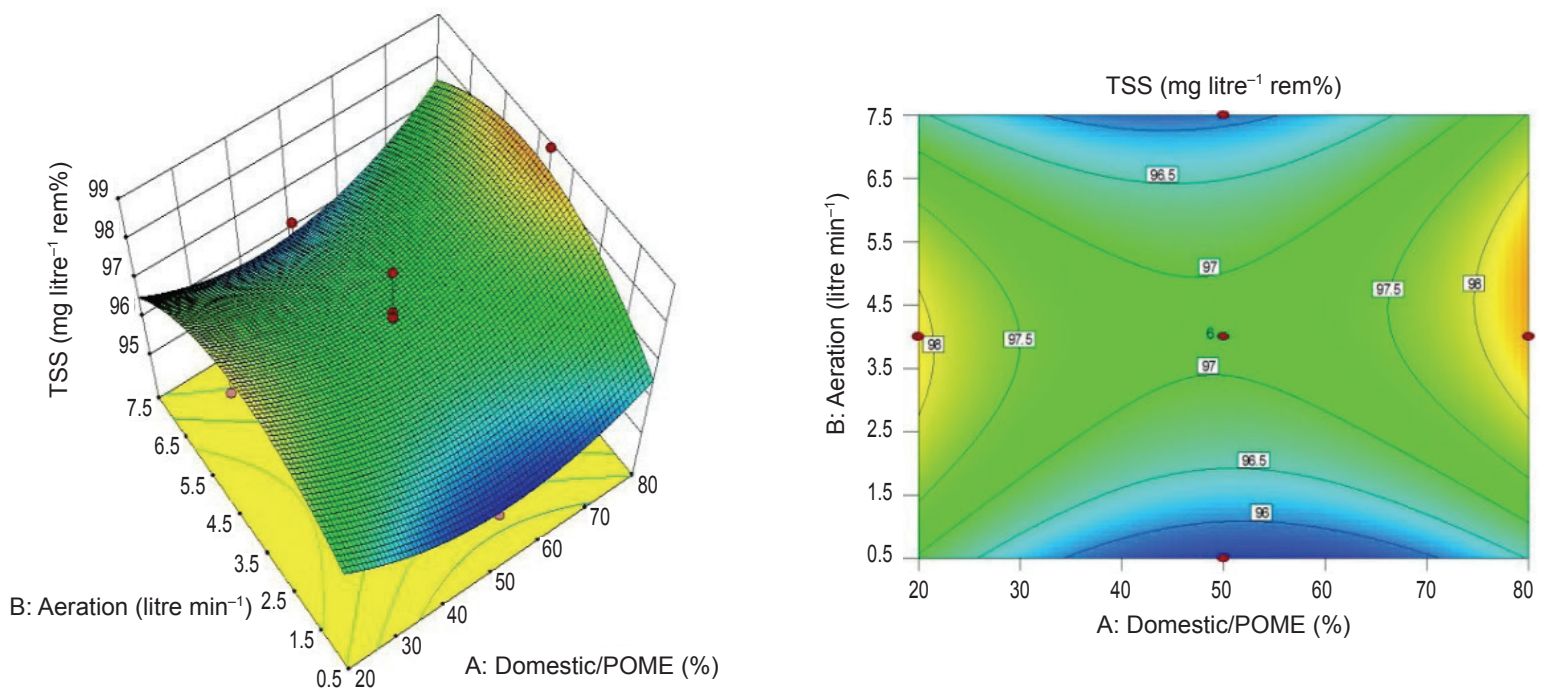

Note: POME - palm oil mill effluent; TSS - total suspended solids.

Figure 7. The 3D surface plots and 2D contour plot for TSS removal. 

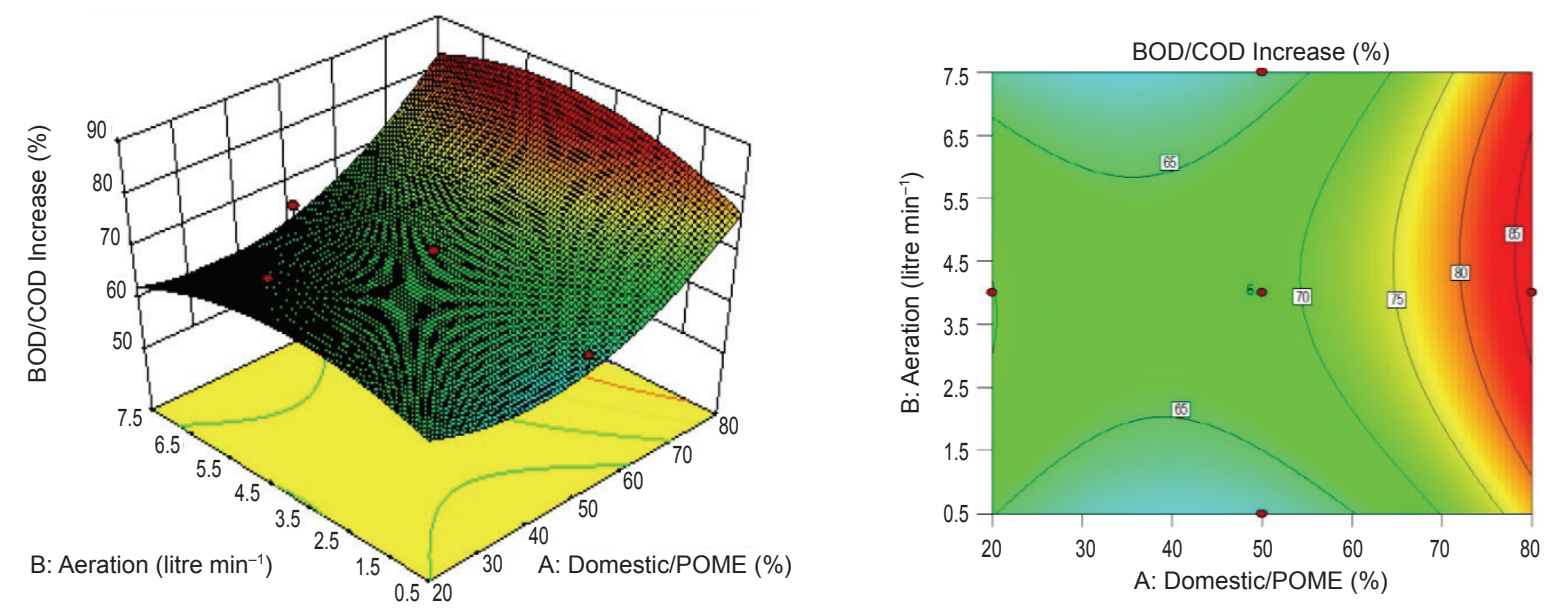

Note: POME - palm oil mill effluent; BOD - biochemical oxygen demand.

Figure 8. The 3D surface plots and 2D contour plot for POME biodegradability.

TABLE 7. REMOVAL POME COMPONENTS IN THE NEW-SBR UNDER DIFFERENT CONDITION

\begin{tabular}{|c|c|c|c|c|}
\hline Parameters & $\begin{array}{l}\text { POME (control) } \\
\text { removal }(\%)\end{array}$ & $\begin{array}{l}\text { Zeolite + POME } \\
\text { removal }(\%)\end{array}$ & $\begin{array}{l}\text { DWW+ POME } \\
\text { removal }(\%)\end{array}$ & $\begin{array}{c}\text { Zeolite + DWW + POME } \\
\text { removal }(\%)\end{array}$ \\
\hline TSS (mg litre ${ }^{-1}$ ) & -22 & 23 & 77 & 98.95 \\
\hline COD (mg litre $\left.{ }^{-1}\right)$ & 9 & 10 & 74 & 98.31 \\
\hline Colour (Pt. Co.) & -30 & 9.6 & 76 & 81.64 \\
\hline $\mathrm{AN}\left(\mathrm{mg}\right.$ litre $\left.^{-1}\right)$ & 69 & 80 & 90 & 98.30 \\
\hline
\end{tabular}

Note: POME - palm oil mill effluent; SBR - sequencing batch reactor; DWW - domestic wastewater; TSS - total suspended solids; $\mathrm{COD}$ - chemical oxygen demand; AN - ammonia nitrogen.

Table 2 illustrates that the anaerobic treatment of POME did not successfully removed colour (2550 Pt. Co.), AN (94.5 mg litre-1), COD (11 $090 \mathrm{mg}$ litre $^{-1}$ ) and TSS (4310 $\left.\mathrm{mg} \mathrm{litre}^{-1}\right)$. As shown in Table 7 , the negative values of TSS $(-22)$ and colour $(-30)$ show that the TSS and colour were increased in the POME due to strong mixing power of the aeration system on the suspended solids. However, in other cases, the presence of adsorbent (natural zeolite) and microbial degradation source (DWW) is a reason to increase removal efficiency of TSS (from $-22 \%$ in POME to $23 \%$ in PMOE + zeolite, $77 \%$ in PMOE + DWW and 98.9\% in PMOE + zeolite+ DWW) and colour (from -30\% in POME to $9.6 \%$ in PMOE + zeolite, $76 \%$ in PMOE + DWW and $81.6 \%$ in PMOE + zeolite + DWW). The results indicate that removal of TSS, AN, COD and colour in the new-SBR with DWW (POME + DWW) is higher than those in both blank new-SBR (POME) and the new-SBR with zeolite (POME + zeolite). Therefore, DWW has a significantly higher influence on POME decontamination compared to the zeolite. The results indicate that the new-SBR with augmentation of DWW and zeolite (POME + DWW + zeolite) was able to remove a high percentage of all pollutants compared to the new-SBR with the only DWW. In sum, the removal efficiency of the new-SBR systems can be sorted as the following order: DWW + POME
+ zeolite $>$ POME + DWW $>$ POME + zeolite $>$ POME. In can be concluded that using both zeolite and DWW improves biodegradability and shortens treatment duration of POME treatment.

\section{Optimisation of Experimental Conditions and Statistical Analysis}

In this section, the RSM and CCD were employed to determine the optimum conditions of the independent factors. In this analysis, DWW/ POME ratio, aeration rate (litre $\mathrm{min}^{-1}$ ), and the contact time (hr) were chosen as independent variables. To conduct a sufficient analysis for the aerobic method of the new-SBR, five dependent variables of TSS, BOD, COD, AN and colour were considered as responses. The effects of operational factors and responses of RSM modeling are presented in Table 8. The RSM results illustrated the specific effect of the independent parameters as well as the influence of the interactive effects on the selected responses. These results indicated that DWW / POME ratio has a significant positive effect on COD, AN and colour removal with $\mathrm{P}$-value $<0.05$ and a low effect on $\mathrm{BOD}_{5}(\mathrm{P}$-value $=0.5681)$ and TSS $(P$-value $=0.6456)$. Moreover, a P-value of 0.0007 for $\mathrm{BOD}_{5} / \mathrm{COD}$ indicates that POME biodegradability is significantly affected by DWW / POME. 
TABLE 8. RESPONSES AND THE EFFECTS OF OPERATIONAL FACTORS FOR RSM MODELING

\begin{tabular}{|c|c|c|c|c|c|c|c|c|c|c|}
\hline Responses & Intercept & $A^{*}$ & B & C & AB & $\mathrm{AC}$ & BC & $A^{\wedge} 2$ & $\mathrm{~B}^{\wedge} 2$ & $C^{\wedge} 2$ \\
\hline TSS & 97.0674 & 0.1330 & 0.1540 & 0.5820 & 0.3463 & 0.1038 & -0.0288 & 1.1691 & -1.3459 & 0.9741 \\
\hline P-value** & & 0.6456 & 0.5951 & 0.0648 & 0.2954 & 0.7476 & 0.9288 & 0.0537 & 0.0306 & 0.0986 \\
\hline $\mathrm{BOD}_{5}$ & 89.5549 & 0.1270 & 0.1930 & 0.2320 & 0.1075 & 0.2325 & 0.0825 & -0.0423 & -0.1723 & 0.6827 \\
\hline P-value & & 0.5681 & 0.3908 & 0.3063 & 0.6645 & 0.3566 & 0.7387 & 0.9200 & 0.6835 & 0.1271 \\
\hline COD & 96.7792 & 0.8310 & 0.1210 & 0.2960 & 0.2363 & 0.2063 & -0.1463 & 0.9845 & -0.7155 & -0.2705 \\
\hline P-value & & 0.0007 & 0.4959 & 0.1145 & 0.2453 & 0.3066 & 0.4625 & 0.0130 & 0.0532 & 0.4268 \\
\hline Colour & 69.4014 & 4.9930 & 2.3030 & 2.7830 & 1.3038 & 1.3938 & -0.9713 & 8.0191 & -7.0409 & -1.5709 \\
\hline P-value & & 0.0337 & 0.2830 & 0.2004 & 0.5783 & 0.5528 & 0.6778 & 0.0651 & 0.0989 & 0.6934 \\
\hline $\mathrm{AN}$ & 97.8850 & 0.4000 & 0.1260 & 0.1050 & - & - & - & - & - & - \\
\hline P-value & & 0.0096 & 0.3680 & 0.4514 & - & - & - & - & - & - \\
\hline $\mathrm{BOD}_{5} / \mathrm{COD}$ & 68.6273 & 8.2000 & 0.6000 & 2.2000 & 2.0000 & 1.2500 & -1.7500 & 9.6818 & -6.3182 & -4.3182 \\
\hline P-value & & 0.0007 & 0.7318 & 0.2253 & 0.3181 & 0.5262 & 0.3795 & 0.0138 & 0.0802 & 0.2130 \\
\hline
\end{tabular}

Note: RSM - response surface methodology.

${ }^{*} \mathrm{~A}$ - MWW / POME ratio, B - aeration rate and C - contact time.

${ }^{* *} \mathrm{P}$-value $<0.05$ - significant and P-value $>0.05$ - no significant.

TSS - total suspended solids; COD - chemical oxygen demand; AN - ammonia nitrogen; BOD - biochemical oxygen demand.

TABLE 9. DEVELOPED EQUATIONS AND ANOVA RESULTS FOR RESPONSE PARAMETERS

\begin{tabular}{|c|c|c|c|c|c|c|c|c|}
\hline Responses* & Modified equations with significant terms ${ }^{* *}$ & Prob. ${ }^{* *}$ & $\mathbf{R}^{2}$ & $\begin{array}{c}\text { Adjusted } \\
\mathbf{R}^{2}\end{array}$ & $\begin{array}{l}\text { Adequate } \\
\text { precision }\end{array}$ & SD & CV & Press $^{* * *}$ \\
\hline TSS & $99.47+0.80 \mathrm{~A}-0.18 \mathrm{C}-7.14 \mathrm{AC}-0.11 \mathrm{~A}^{2}+9.5 \mathrm{C}^{2}$ & 0.24 & 0.71 & 0.66 & 3.53 & 1.16 & 1.19 & 121.3 \\
\hline $\mathrm{BOD}_{5}$ & $90.15+0.09 \mathrm{~A}+-0.17 \mathrm{C}+2.86 \mathrm{AC}+-0.02 \mathrm{~A}^{2}-+6 \mathrm{C}^{2}$ & 0.67 & 0.54 & 0.45 & 2.72 & 0.74 & 0.82 & 23.5 \\
\hline COD & $96.07+0.63 \mathrm{~A}+0.09 \mathrm{C}-6.42 \mathrm{AC}-0.08 \mathrm{~A}^{2}+-2.62 \mathrm{C}^{2}$ & 0.35 & 0.54 & 0.45 & 5.81 & 0.89 & 0.92 & 15.12 \\
\hline Colour & $65.61+6.04 \mathrm{~A}+0.88 \mathrm{C}-0.02 \mathrm{AC}-0.711 \mathrm{~A}^{2}-0.03 \mathrm{C}^{2}$ & 0.44 & 0.68 & 0.62 & 3.26 & 9.08 & 13.02 & 7472.5 \\
\hline AN & $95.61-0.06 \mathrm{~A}-0.06 \mathrm{C}+3.57 \mathrm{AC}+0.02 \mathrm{~A}^{2}+4.18 \mathrm{C}^{2}$ & 0.10 & 0.82 & 0.77 & 5.18 & 0.5 & 0.51 & 12.11 \\
\hline $\mathrm{BOD}_{5} / \mathrm{COD}$ & $63.05+5.04 \mathrm{~A}+1.65 \mathrm{C}-0.05 \mathrm{AC}-0.65 \mathrm{~A}^{2}-0.06 \mathrm{C}^{2}$ & 0.18 & 0.86 & 0.83 & 5.53 & 6.97 & 10.15 & 3026 \\
\hline
\end{tabular}

Note: *All removal units are mg litre ${ }^{-1}$ except $\mathrm{BOD}_{5} / \mathrm{COD}$ (unit less).

**In final equations, where A - DWW / POME (\%); B - the aeration rate (litre $\left.\mathrm{min}^{-1}\right)$; C - contact time (hr).

***Prob. - the probability of error; $\mathrm{R}^{2}$ - coefficient of determination; SD - standard deviation; CV - coefficient of variance;

**** Press - predicted residual error sum of square. ANOVA - analysis of variance.

TSS - total suspended solids; COD - chemical oxygen demand; AN - ammonia nitrogen; BOD - biochemical oxygen demand.

The second-order functions of pollutant removal including the results of ANOVA analysis are shown in Table 9. These equations express the relationship between independent parameters and the reduction of TSS, BOD, COD, AN, colour and $\mathrm{BOD}_{5} / \mathrm{COD}$. It was noted that the regression model for the reduction of pollutant was significant at a confidence level of $95 \%(\mathrm{p}<0.05)$ with $\mathrm{R}^{2}$ equal to $0.86,0.82,0.71,0.680 .54,0.54$ and for $\mathrm{BOD}_{5} /$ COD, AN, TSS, colour, BOD and COD respectively. The coefficient of determination $\left(R^{2}\right)$ indicates that although the regression model was able to successfully predict $\mathrm{BOD}_{5} / \mathrm{COD}\left(\mathrm{R}^{2}=0.86\right)$ and $\mathrm{AN}$ $\left(R^{2}=0.82\right)$, other techniques such as soft computing methods can be recommended to prodive higher accuracy for other parameters (Zakaria et al., 2010; Mohammadpour et al., 2014; 2018; 2019; Ghani and Mohammadpour, 2015; Mohammadpour, 2017). A comparison between actual and predicted TSS and COD removal is illustrated in Figure 9.
Finding the optimum point of each element (aeration rate, contact time and DWW/POME ratio) could produce a clear picture for achieving the highest performance of decontamination. Based on the predicted model, the highest desirability of treatment (0.988) could be achieved in optimum operation conditions (contact time of $17.9 \mathrm{hr}$, DWW/POME ratio of 58.7\%, and aeration rate of 6.85 litre $\mathrm{min}^{-1}$ ). Under these conditions, COD, BOD, colour, AN and TSS removal rates were $96.80 \%, 90.1 \%, 69.90 \%, 98.20 \%$ and $97.20 \%$, respectively. This research highlights that the recommended system can be successfully used as a cost-effective methods for post-treatment of POME. This system is able to highly remove the pollution within a short time (less than a day). Therefore, it can be commonly used as a rapid, economic and highly reliable technique to remove pollution and treat wastewater at any aquatic system worldwide. 

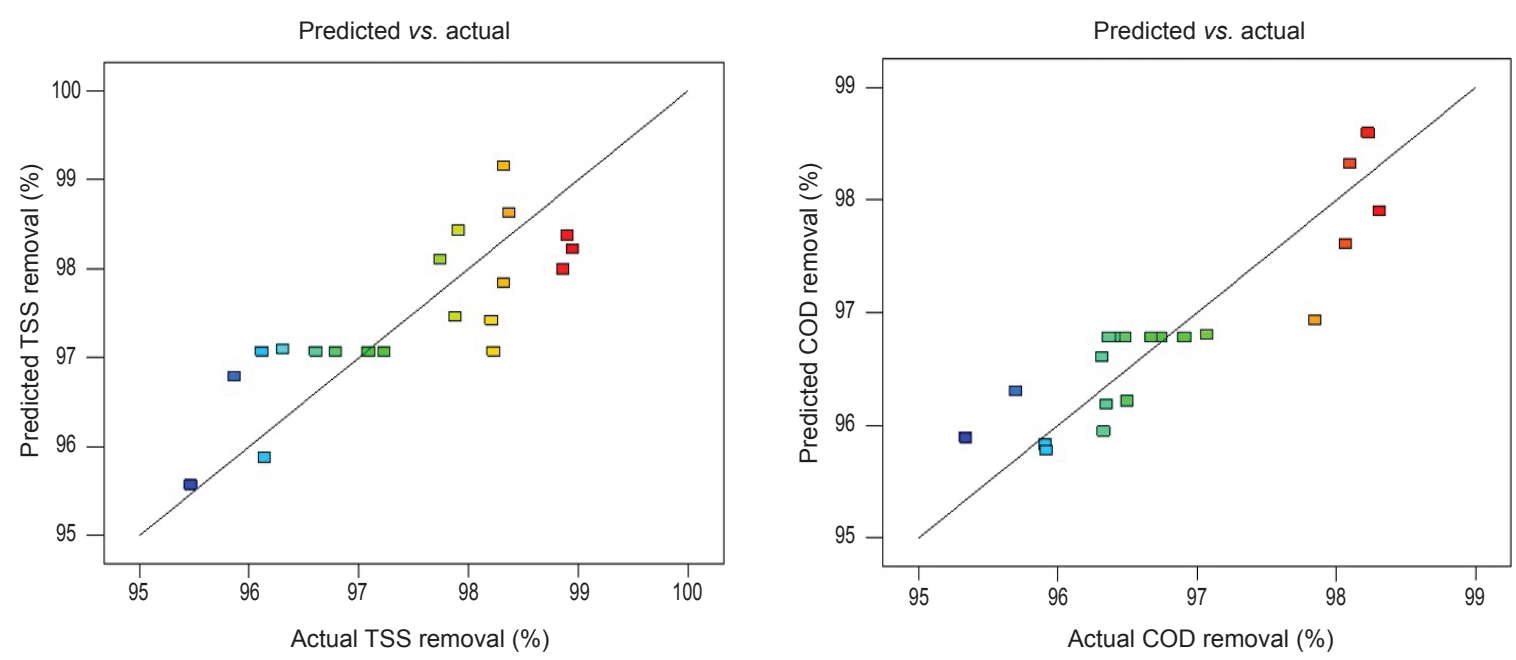

Note: TSS - total suspended solids; COD - chemical oxygen demand.

Figure 9. Experimental vs. predicted (a) TSS removal; (b) COD removal.

\section{CONCLUSION}

The POME with high pollution components can be considered as an ecosystem and environmental hazard if it is discharged without any treatment to the environment. SBR is recommended to biologically treat wastewater and POME. In this study, a novel and cost-effective aeration system namely the new-SBR with opposite direction of aeration was developed to achieve a high efficiency of aeration in SBR. The DWW and zeolite were employed as an available microbial source and new adsorbent, respectively to improve the new-SBR treatment duration. A high pollution removal was obtained using the new-SBR. The COD, BOD, TSS, $\mathrm{AN}$ and colour removal rates were found in the range of $95.34 \%-98.31 \%, 88.79 \%-91.44 \%, 95.47 \%$ $98.95 \%, 96.19 \%-98.30 \%$ and $56.94 \%-81.64 \%$, respectively. Several extra experiments have been conducted with and without zeolite and DWW to determine the ability of these materials in POME treatment. The results indicate that the new-SBR with adding both DWW and zeolite (POME+DWW+zeolite) is able to remove a high percentage of all pollution in compare to the newSBR with only DWW or zeolite. In sum, the removal efficiency of the new-SBR systems can be sorted as the following order: POME + DWW + zeolite > POME +DWW $>$ POME + zeolite $>$ POME. It can be concluded that using both zeolite and DWW improves biodegradability and shortens treatment duration of POME treatment. The RSM and CCD methodology have been used to determine the optimum values of the independent parameters, including contact time $(\mathrm{hr})$, aeration rate (litre $\mathrm{min}^{-1}$ ), and ratio of domestic wastewater to POME $(\mathrm{DWW} / \mathrm{POME} ; \mathrm{v} / \mathrm{v})$, as well as their dependent parameters (COD, BOD, colour, AN and TSS). The highest desirability of POME treatment (0.988) was achieved in optimum operation conditions (DWW/POME ratio of $58.7 \%$, aeration rate of 6.85 litre $\mathrm{min}^{-1}$, and contact time of $17.9 \mathrm{hr}$ ). Under these conditions, COD, BOD, colour, AN and TSS removal rates were $96.80 \%, 90.1 \%, 69.90 \%, 98.20 \%$ and $97.20 \%$, respectively. Finally, an ANOVA analysis indicated that DWW/POME ratio has a significant positive effect on COD, AN and colour removal and low effect on $\mathrm{BOD}_{5}$ and TSS removal.

\section{ACKNOWLEDGEMENT}

This work is funded by the Solid Waste Management Cluster, Engineering Campus, Universiti Sains Malaysia under Iconic Grant Scheme (Grant No. 1001 / CKT / 870023). We gratefully acknowledge the financial support from the Institute of Standard and Industrial Researches of Iran (ISIRI).

\section{REFERENCES}

Ahmad, A L; Suzylawati Ismail and Subhash Bhatia (2003). Water recycling from palm oil mill effluent (POME) using membrane technology. Desalination, 157(1): 87-95.

APHA (2017). Standard Methods for the Examination of Water and Wastewater. 23 $3^{\text {st }}$ Edition. American Water Works Association/American Public Works Association/Water Environment Federation.

Aziz, S Q; Aziz, H A; Yusoff, M S and Bashir, M J (2011a). Landfill leachate treatment using powdered activated carbon augmented sequencing batch 
reactor (SBR) process: Optimization by response surface methodology. J. Hazardous Materials, 189: 404-413.

Aziz, S Q; Aziz, H A and Yusoff, M S (2011b). Optimum process parameters for the treatment of landfill leachate using powdered activated carbon augmented sequencing batch reactor (SBR) technology. Separation Science and Technology, 46: 2348-2359.

Aziz, S Q; Aziz, D; Abdul, H; Yusoff, M S; Mojiri, A and Amr, S A (2012). Adsorption isotherms in landfill leachate treatment using powdered activated carbon augmented sequencing batch reactor technique: Statistical analysis by response surface methodology. Int. J. Chemical Reactor Engineering, 10(89): 21.

Aziz, S Q; Aziz, H A; Mojiri, A; Bashir, M J and Abu Amr, S (2013). Landfill leachate treatment using sequencing batch reactor (SBR) process: Limitation of operational parameters and performance. Int. J. Scientific Research in Knowledge, 1: 34-43.

Borja, R and Banks, C J (1995). Comparison of an anaerobic filter and an anaerobic fluidized bed reactor treating palm oil mill effluent. Process Biochem., 30: 511-521.

Chan, Y J; Chong, M F and Law, C L (2012). An integrated anaerobic-aerobic bioreactor (IAAB) for the treatment of palm oil mill effluent (POME): Start-up and steady state performance. Process Biochemistry, 47(3): 485-495.

Chan, Y J; Chong, M F and Law, C L (2011). Optimization on thermophilic aerobic treatment of anaerobically digested palm oil mill effluent (POME). Biochemical Engineering J., 55(3): 193-198.

Chan, Y J; Chong, M F and Law, C L (2010). Biological treatment of anaerobically digested palm oil mill effluent (POME) using a lab-scale sequencing batch reactor (SBR). J. Environmental Management, 91: 1738-1746.

Chin, K K; Ng, W J and Ma, A N (1987). Palm oil refinery effluent treatment by sequencing batch reactors. Biological Wastes, 20(2): 101-109.

Chin, M J; Poh, P E; Tey B T; Chan, E S and Chin, K L (2013). Biogas from palm oil mill effluent (POME): Opportunities and challenges from Malaysia's perspective. Renewable and Sustainable Energy Reviews, 26: 717-726.

Chou, K W; Tan, S W; Morad, N; Tow, T T; Kadir, $\mathrm{M} \mathrm{O}$ and Ismail, N (2016). Aerobic post-treatment of different anaerobically digested palm oil mill effluent (POME). Int. J. Environmental Science and Development, 7(7): 511.

Darajeh, N; Idris, A; Truong, P; Abdulaziz, A; Abubakar, R and Cheman, H (2014). Phytoremediation potential of vetiver system technology for improving the quality of palm oil mill effluent. Advances in Materials Science and Engineering, Vol. 2014 (4): 1-10.

Drinan, J E and Spellman, F (2012). Water and Wastewater Treatment: A Guide for the Nonengineering Professional. CRC Press. 300 pp.

Erdem, E; Karapinar, N and Donat, R (2004). The removal of heavy metal cations by natural zeolites. J. Colloid and Interface Science, 280(2): 309-314.

Faisal, M and Unno, H (2001). Kinetic analysis of palm oil mill wastewater treatment by a modified anaerobic baffled reactor. Biochem. Eng. J., 9: 25-31.

Fun, C W; Haq, M R U and Kutty, S R M (2007). Treatment of palm oil mill effluent using biological sequencing batch reactor system. WIT Transactions on Ecology and the Environment Vol. 104. Southampton, United Kingdom. WIT Press. p. 511-518.

Ghani, A A and Mohammadpour, R (2015). Temporal variation of clear-water scour at compound abutments. Ain Shams Engineering J., 7: 1045-1052.

Garbossa, L H P; Lapa, K R; Zaiat, M and Foresti, $\mathrm{E}$ (2005). Development and evaluation of a radial anaerobic/aerobic reactor treating organic matter and nitrogen in sewage. Brazilian J. Chemical Engineering, 22(4): 511e519.

Gerardi, M H (2011). Troubleshooting the Sequencing Batch Reactor. John Wiley \& Sons. 216 pp.

Halim, A A; Aziz, H A; Johari, M A M and Ariffin, K S (2010). Comparison study of ammonia and COD adsorption on zeolite, activated carbon and composite materials in landfill leachate treatment. Desalination, 262(1): 31-35.

Ho, C C and Tan, Y K (1983). Centrifugal fractionation studies on the particulates of palm oil mill effluent. Water Research, 17(6): 613-618.

Igwe, J C; Onyegbado, C O and Abia, A A (2010). Studies on the kinetics and intraparticle diffusivities of $\mathrm{BOD}_{5}$, colour and TSS reduction from palm oil mill effluent (POME) using boiler fly ash. African J. Environmental Science and Technology, 4(6): 392-400. 
Ismail, M H S; Dalang, S; Syam, S and Izhar, S (2013). A study on zeolite performance in waste treating ponds for treatment of palm oil mill effluent. J. Water Resource and Protection, 5(07): 18.

Jenícek, P; Dohányos, M and Zábranská, J (1999). Combined anaerobic treatment of wastewaters and sludges. Water Science and Technology, 40(1): 85-91.

Kalló, D (2001). Applications of natural zeolites in water and wastewater treatment. Reviews in Mineralogy and Geochemistry, 45(1): 519-550.

Kamarudzaman, A N; Aziz, R A and Jalil, M (2011). Removal of heavy metals from landfill leachate using horizontal and vertical subsurface flow constructed wetland planted with Limnocharis flava. Int. J. Civil and Environmental Engineering, 11: 85-91.

Kesraoui-Ouki, S; Cheeseman, C R and Perry, $R$ (1994). Natural zeolite utilisation in pollution control: A review of applications to metals' effluents. J. Chemical Technology and Biotechnology: Int. Research in Process, Environmental and Clean Technology, 59(2): 121-126.

Khemkhao, M; Techkarnjanaruk, S and Phalakornkule, C (2015). Simultaneous treatment of raw palm oil mill effluent and biodegradation of palm fiber in a high-rate CSTR. Bioresource Technology, 177: 17-27.

Li, X; Zhao, Q and Hao, X (1999). Ammonium removal from landfill leachate by chemical precipitation. Waste Management, 19: 409-415.

Liew, W L; Kassim, M A; Muda, K; Loh, S K and Affam, A C (2015). Conventional methods and emerging wastewater polishing technologies for palm oil mill effluent treatment: A review. J. Environmental Management, 149: 222-235.

Lim, Y L; Ho, Y C and Alkarkhi, A F M (2014). Application of optimization in wastewater treatment. Wastewater engineering: Types, characteristics and treatment technologies. IJSR Publications. https:// books.google.com.my/books?id=sv6MAwAAQBAJ, p. $225-237$.

Ma, A N and Ong, A S H (1988). Treatment of palm oil steriliser condensate by an anaerobic process. Biological Wastes, 23(2): 85-97.

Ma, A; Cheah, S; Chow, M and Yeoh, B (1993). Current status of palm oil processing waste management. Waste Management in Malaysia: Current Status and Prospects for Bioremediation (Yeoh, B S et. al). p. 111136.
Mansor, U Q; Yahya, A; Shafie, N F; Roslan, Q I; Manshor, N M; Som, A M; Nour, Z H and Yunus, R M (2017). An overview of anaerobic treatment processes performance treating palm oil mill effluent (POME) past, present and future. Advanced Science Letters, 23(5): 4179-4183.

Metcalf and Eddy (2014). Wastewater EngineeringTreatment and Reuse. $4^{\text {th }}$ Edition. McGraw Hill, Inc.

Mohammed, R R and Chong, M F (2014). Treatment and decolorization of biologically treated palm oil mill effluent (POME) using banana peel as novel biosorbent. J. Environ. Manage., 132: 237-249.

Mohammadpour, R; Shaharuddin, S; Chang, C; Zakaria, N; Ghani, A and Chan, N (2014). Prediction of water quality index in constructed wetlands using support vector machine. Environmental Science and Pollution Research, 22(1): 6206-6219.

Mohammadpour, R (2017). Prediction of local scour around complex piers using GEP and M5-Tree. Arabian J. Geosciences, 10: Article No. 416.

Mohammadpour, R; Asaie, Z; Shojaeian, M R and Sadeghzadeh, M (2018) A hybrid of ANN and CLA to predict rainfall. Arabian J. Geosciences, 11: 533.

Mohammadpour, R; Ghani, A A; Sabzevari, T and Fared Murshed, M (2019). Local scour around complex abutments. ISH J. Hydraulic Engineering. DOI: $10.1080 / 09715010.219 .1607783$.

Mohan, S V and Karthikeyan, J (1997). Removal of lignin and tannin colour from aqueous solution by adsorption onto activated charcoal. Environ. Pollu., 97(1): 183-187.

Mojiri, A; Aziz, H A; Zaman, N Q; Aziz, S Q and Zahed, M A (2014). Powdered ZELIAC augmented sequencing batch reactors (SBR) process for co-treatment of landfill leachate and domestic wastewater. J. Environ. Manage., 139: 1-14.

Montalvo, S; Guerrero, L; Borja, R; Sánchez, E; Milán, Z; Cortés, I and De la la Rubia, M A (2012) Application of natural zeolites in anaerobic digestion processes: A review. Applied Clay Science, 58: 125-133.

Moradi, A; Teh, B S C; Goh, K J; Husni, M H A and Fauziah, I C (2015). Effect of four soil and water conservation practices on soil physical processes in a non-terraced oil palm plantation. Soil Tillage. Res., 145: 62-71.

Moussavi, G; Talebi, S; Farrokhi, M and Sabouti, R M (2011). The investigation of mechanism, 
kinetic and isotherm of ammonia and humic acid co-adsorption onto natural zeolite. Chemical Engineering J., 171(3): 1159-1169.

Nasrullah, M; Singh, L; Mohamad, Z; Norsita, $\mathrm{S}$; Krishnan, S; Wahida, $\mathrm{N}$ and Zularisam, A W (2017). Treatment of palm oil mill effluent by electrocoagulation with presence of hydrogen peroxide as oxidizing agent and polialuminum chloride as coagulant-aid. Water Resources and Industry, 17: 7-10.

Najafpour, G D; Zinatizadeh, A A L; Mohamed, A R; Hasnain Isa, M and Nasrollahzadeh, H (2006). Highrate anaerobic digestion of palm oil mill effluent in an upflow anaerobic sludge-fixed film bioreactor. Process Biochemistry, 41(2): 370-379.

Neczaj, E; Kacprzak, M; Lach, J and Okoniewska, E (2007). Effect of sonication on combined treatment of landfill leachate and domestic sewage in SBR reactor. Desalination, 204(1): 227-233.

Ng, F Y; Yew, F K; Basiron, Y and Sundram, K (2012). A renewable future driven with Malaysian palm oilbased green technology. J. Oil Palm, Environment and Health (JOPEH), 2: 1-7.

Oswal, N; Sarma, P M; Zinjarde, S S and Pant, A (2002). Palm oil mill effluent treatment by a tropical marine yeast. Bioresource Technology, 85(1): 35-37.

Sahu, J; Agarwal, S; Meikap, B and Biswas, M (2009). Performance of a modified multi-stage bubble column reactor for lead (II) and biological oxygen demand removal from wastewater using activated rice husk. J. Hazardous Materials, 161: 317324.

Shavandi, M A; Haddadian, Z; Ismail, M H S and Abdullah, N (2012). Continuous metal and residual oil removal from palm oil mill effluent using natural zeolite-packed column. J. Taiwan Institute of Chemical Engineers, 43: 934-941.

Setiadi, T and Husaini, A (1996). Palm oil mill effluent treatment by anaerobic baffled reactors: Recycle effects and biokinetic parameters. Water Sci. Technol., 34: 59-66.

Vijayaraghavan, K; Ahmad, D and Aziz, M A (2007). Aerobic treatment of palm oil mill effluent. J. Environmental Management, 82: 24-31.

Wong, W H; Lee, W X; Ramanan, R N; Tee, L H; Kong, K W; Galanakis, C M; Sun, J and Prasad, K N (2015). Two level half factorial design for the extraction of phenolics, flavonoids and antioxidants recovery from palm kernel by-product. Industrial Crops and Products, 63: 238-248.

Yacob Hassan, M A; Shirai, Y; Wakisaka, M and Subash, S (2006). Baseline study of methane emission from anaerobic ponds of palm oil mill effluent treatment. Sci. Total Environ., 366: 187-196.

Zahrim, A; Rachel, F; Menaka, S; Su, S; Melvin, F and Chan, E (2009). Decolourisation of anaerobic palm oil mill effluent via activated sludge-granular activated carbon. World Appl. Sci. J., 5: 126-129.

Zakaria, N A; Azamathulla, H M; Chang, C K and Ghani, A A (2010). Gene expression programming for total bed material load estimation - A case study. Science of the Total Environment, 408: 50785085 .

Zhang, Y; Li, Y A N; Xiangli, Q I A O; Lina, C H I; Xiangjun, N I U; Zhijian, M E I and Zhang, Z (2008). Integration of biological method and membrane technology in treating palm oil mill effluent. $J$. Environmental Sciences, 20(5): 558-564. 